\title{
Small retailers in/out of the crisis in Germany - Re-inventing Retailing
}

\author{
Cornelia Scott $^{*}$, and Vanessa Fehlig \\ Anhalt University of Applied Sciences, Department of Economics and Business Management, 06406 Bernburg (Saale), Germany
}

\begin{abstract}
The year 2020 required many changes in all areas of life as a result of the Covid-pandemic. Both privately and professionally, we had to deal with new challenges. The economy in Germany and especially the in-store retail sector was affected severely by the lock-downs. Small retail businesses are especially threatened because of their low financial reserves and many insolvencies are imminent. This is very dramatic because, on the one hand, many livelihoods are directly linked to these small retailers. On the other hand about $94 \%$ of the sectors are currently so called micro or small enterprises with less than 10 or 50 employees and an annual turnover under 2 or 10 million euros. These "local shops" are a characteristic of city centers and important for the economic stability and diversity of the country. To support these businesses, the state has introduced various direct financial aids and indirect ones such as short-time work or guarantees. Regardless of the difficulties associated with applying for and receiving aid, it is also the responsibility of retailers to use change management skills to develop their own solutions. Covid has now dramatically shown where unused potential exists, e.g. through the implementation of multi-channel or hybrid business models. As dramatic as the situation is, it should also be used as an opportunity to increase innovative skills and to take a purposeful approach to the transformative process.
\end{abstract}

\section{The corporate landscape in Germany}

The corporate structure in Germany shows a clear picture, as a total of $99.4 \%$ of companies are so called "KMUs" (Kleine und mittlere Unternehmen / small and medium-sized enterprises). Of these, micro-enterprises take up the largest share with $81.8 \%$. The companies are differentiated on the basis of the number of employees and turnover. [1-3]

Table 1. KMU - Enterprise size categories in Germany

\begin{tabular}{|c|c|c|}
\hline & $\begin{array}{c}\text { Number of } \\
\text { employees }\end{array}$ & Turnover \\
\hline $\begin{array}{c}\text { Micro- } \\
\text { enterprises }\end{array}$ & $<10$ & $\begin{array}{c}\text { Annual turnover or } \\
\text { annual balance sheet } \\
\text { total } \leq € 2 \text { million }\end{array}$ \\
\hline $\begin{array}{c}\text { Small } \\
\text { enterprises }\end{array}$ & $<50$ & $\begin{array}{c}\text { Annual turnover or } \\
\text { annual balance sheet } \\
\text { total } \leq € 10 \text { million }\end{array}$ \\
\hline $\begin{array}{c}\text { Medium } \\
\text { enterprises }\end{array}$ & $<250$ & $\begin{array}{c}\text { Annual turnover } \leq € 50 \\
\text { million o. annual balance } \\
\text { sheet total } \leq € 43 \text { million }\end{array}$ \\
\hline
\end{tabular}

The crisis induced by Corona affects the majority of the German economy, but micro-enterprises are particularly affected, especially in the retail sector. These represent the largest number of enterprises with about $79.6 \%$. Despite the large number, micro-enterprises were already losing more and more market share before
Corona, so that turnover fell to only about $15 \%$ of total turnover in the sector. Corona has now accelerated this process and threatens the existence of many retailers. These little "shops", which invite people to spend time strolling and browsing in the city centre, are particularly affected by the economic consequences of the crisis. Often there are no large financial reserves and the distribution channel is primarily focused on local, direct sales. As a result of the initially optional and later mandatory closures of shops as part of the lockdowns in the spring and winter of 2020, resulted in a high loss of demand, with the exception being supplies of daily goods. In the stationary retail sector, the decrease in sales since the second lockdown in December has been persistent at around $80 \%$, so that $52 \%$ of businesses reported that the impact would be so severe that, without further assistance, they might have to quit their business in 2021. [4-7]

\section{State aid measures for the retailer in Germany}

With the intention of supporting businesses quickly in the crisis, the federal government has expanded and simplified existing measures and adopted additional programmes. One of the most popular instruments is financing by loans. Special support is available, for example, from the Kreditanstalt für Wiederaufbau (KFW) in the form of fast-track loans with federal guarantee. Approximately 40,000 fast-track loans have been applied for so far. [8] 
Another measure that has been established in Germany for years is short-time work (Kurzarbeit). This measure is primarily intended to save employment when a low order situation results in low capacity utilisation and thus also in financial loss. Due to the effects of the Corona pandemic, special regulations were enacted for the receiving of short-time work payments. The current requirements are that at least $10 \%$ of the employees have a loss of work hours and related wages of more than $10 \%$ as well as that the overtime has been reduced. If these conditions are achieved, a company can apply for short-time work. The reference period has been extended to a maximum of 24 months. If the application is approved, the company pays the employees the wages earned plus the short-time allowance for the lost wages. Upon application, the short-time allowance will be refunded to the company for the previous month with retroactive effect. The short-time allowance amounts to $60 \%$ of the net final salary for the first three months or $67 \%$ for employees with children. The benefits increase in two stages to a maximum of $80 \%$ or $87 \%$ after seven months. In addition, social security contributions, minus unemployment insurance, are also reimbursed, thus additionally reducing the burden on the company. $[9,10]$

In 2020, 1,082,500 companies applied for short-time work across all sectors, which affected a total of $14,403,789$ people. $57.7 \%$ of the companies made their application in April, i.e. in the period of the first lockdown. To be able to classify the dimensions, in 2019 there were only 16,420 applications for short-time work. Especially in small companies, as well as in the retail sector, this support was used a lot. Thus, $11 \%(116,637)$ of all applications came from the retail sector. The number of all employees subject to social insurance contributions in the retail sector who were on short-time work averaged approx. $6.7 \%$ in the period from May to December 2020. Around 74\% of these work in microenterprises and around $94 \%$ in micro or small enterprises with fewer than 50 employees. [11-13]

In addition, there is special support that was introduced due to the pandemic. So called interim aid (Überbrückungshilfen), grants and emergency aid can be applied for or tax payments can be deferred interest-free for a limited period. In total, the federal government has made more than 350 billion euros available for all Corona relief measures and has pledged guarantees amounting to approximately 820 billion euros. [14]

The various aid offers are partly aimed at different target groups and have different eligibility criteria. Companies can apply for several subsidies, but if the subsidy periods overlap, they are offset against each other. At the beginning of the first lockdown, the first interim aid was introduced, which provides funding for June, July and August. The basis of eligibility for this is that the turnover in April and May 2020 must have fallen by at least $60 \%$ on average compared to the same months of the previous year. This assistance should be particularly targeted at small and medium-sized enterprises, which is why an exclusion limit of 750 million euros in annual turnover was introduced. The subsidy amount is $40 \%, 50 \%$ or $80 \%$ of the eligible fixed costs, but a maximum of $€ 50,000$ per month, and is calculated depending on the drop in turnover. In addition, there is a maximum amount of $€ 5,000$ for micro-enterprises. $[15,16]$

Subsequently, the second interim aid for the so called "funding months" September to December 2020 was decided with modified conditions. The prerequisite for receiving the aid is a decline in turnover of at least $50 \%$ in two consecutive months as well as an average decline of at least 30\% in the period from April to August 2020 compared to the corresponding months of the previous year. All enterprises, regardless of sector and size, that meet the eligibility criteria can apply. The subsidy amount has been increased to $40 \%, 60 \%$ or $90 \%$ of the eligible fixed costs, but still amounts to a maximum of $€ 50,000$ per month and is calculated depending on the drop in turnover. [15,16]

In addition to the second lockdown, November and December allowances were decided. The eligibility criteria for these are that the company is affected by the closure ordinance. Companies in the retail sector that only had to close in mid-December are therefore not eligible. [15,16]

The third interim aid covers the funding months November 2020 to June 2021. The requirements were significantly lowered here. A company must show a drop in turnover of at least $30 \%$ in one month compared to the same month of the previous year. Once again, all relevant companies can apply for assistance, but they must not have exceeded an annual turnover of 750 million euros in 2020. The subsidy rates remain at $40 \%$, $60 \%$ or $90 \%$ of eligible fixed costs, but the maximum amount has been increased from $€ 50,000$ per month to $€ 1,500,000$ per month compared to the previous bridging aid. $[15,16]$

With regard to interim aid, a special rule was adopted which allows retailers to declare depreciation on seasonal goods at $100 \%$ as fixed costs, provided they were affected by the closure order and made a deficit in 2020. Previously, only depreciation on fixed assets could be declared at $50 \%$. [17]

Furthermore, there are grants in the form of emergency aid from the federal government for small businesses, which are based on the number of employees and the operating costs for three months, among other factors. Companies with up to five employees receive up to $€ 9,000$ and up to $€ 15,000$ for up to ten employees. These subsidies also do not have to be repaid by the companies. A total of $€ 50$ billion has been made available for this measure. [17,18]

As promising as the measures sounded at first, considerable difficulties have now become apparent in retrospect, especially in the disbursement of aid. By the end of 2020 , only $8 \%$ of the funds available for the first and second interim aid had been approved and disbursed, amounting to only 623.4 million euros. One reason for this is the application requirements, which are perceived as very complicated. For example, companies must have the applications submitted by a tax advisor, accountant, auditor or lawyer. In addition, their capacities are also limited and already at full capacity. Another aspect that slows down the process is that economic aid has to be approved by the EU Commission. [16,19] 
For the retail sector, there is also the problem that, despite closures, the companies are not entitled to the November and December aid and that an application for bridging aid III is only possible since 10 February 2021, which can lead to major liquidity problems. In order to counteract the late payments and to reduce the time until payment via the federal states, advance payments are now to be made by the federal government. [20,21]

Overall, the affected companies are rather dissatisfied with the measures. For example, $81 \%$ of the stationary retail businesses stated that the relief measures were not sufficient to secure their existence. However, in addition to the financial measures, there is also dissatisfaction with the approach and communication to the ongoing lockdown. Although the Robert Koch Institute classifies the risk of infection for retailers as low (if hygiene regulations such as shopping with a mask and a maximum of one person per $10 \mathrm{~m}^{2}$ are observed), there is still no opening concept. Retail representatives are therefore requesting such a concept, e.g. with realistic gradual openings. It is important that the concept applies uniformly, regardless of the size of the company and the federal state, in order to avoid distortions of competition and uncertainties. [5,22,23]

\section{The entrepreneurial spirit of retailers is in demand}

Despite the measures decided by the federal government, there is considerable uncertainty among many retailers: are they really entitled to financial aid, how long will it take for the money to be paid out and will the amount even be enough? Therefore, many retailers were forced to develop their own solutions for the lockdown immediately.

Small retailers in particular face different difficulties from large retail chains due to their shop closures. Until the pandemic, many small shops had no or only a rudimentary online shop or delivery service and tended to rely on the stationary distribution channel, as they had for years. But of course, this was no longer possible overnight due to the lockdown. The entrepreneurial spirit of the retailers is required to find quick and useful solutions for this new situation.

A few practical examples are given below:

Retailer Korbmayer is located in the city center of Stuttgart and stocks exclusive women's and maternity fashion as well as a wide range of baby and children's clothing, prams, children's furniture and toys and gifts from selected brands. In the last 12 months, the company has been presented several times by the German press as a good example of how to adapt to the new challenge lockdown. Before the pandemic, Korbmayer achieved about $98 \%$ of its turnover through stationary sales and had only a small online shop. But the young managing director Florian Henneka did not want to simply accept the perspective of short-time work for his employees with the onset of the lockdown and was also worried about losing customers permanently to online suppliers. He reacted quickly by setting up his online shop. The employees actively participated and quickly found their way into the new tasks: Photographing, online posting, logistics, online customer service. Already in March $2020,1 / 5$ of the usual turnover was achieved through the online shop and in April, about 200 orders per day were already being received and shipped. Henneka is convinced that "without the development of an online shop, he is not sure if the business would have made it into the 6th generation" [8]. Now the online shop is indispensable for the staff and customers. Other sales options, such as video calling, were also quickly added: Online consultations are arranged and customers are invited to a virtual tour of the shop, during which products are demonstrated. The products they like can then be picked up or delivered to their home to try them out. Online shopping events via Zoom/Webex/Microsoft teams are also planned and offer a convenient way for customers to see the products without having to leave home.

For companies without their own online store and no ability to set one up on short notice, there are alternatives such as the website Yourlocal, which enables small companies in Magdeburg to present themselves and their products online. On the website, which was set up in the first lockdown, there are various categories ranging from food, clothing and household goods to restaurants as well as sports and cultural offers, which provide a varied selection. Customers can then request the products and, depending on the shop, pick them up (Click \& Collect) or have them delivered. Thus, businesses are relieved of having to deal with the technical challenges. In addition, there is the advantage that Yourlocal is free of charge and, as a project, has set itself the goal of supporting local retailers in the pandemic by providing a platform. [24]

\section{Seeing the crisis as an opportunity - retailers should develop and be confident in themselves....}

The lockdown has changed buying behaviour, perhaps in the long term, and retailers need to adapt to these changes. Retailers, especially small retailers, need to adapt to this customer behaviour and act instead of react if they want to survive in the market permanently. They must increasingly draw the customer's attention to their strengths and "bind" them to them. Creative, new sales channels (e.g. through online shops, online shopping, social media) must be developed further and a new, different "shopping experience" created. Small shops/stores often live from their flair, they have personality and are run by personalities - personal contacts and advice, a familiar and secure feeling is often what makes these retailers strong. This must be communicated effectively in the sales channels. In personal conversations with retailers in recent months, however, we have often also heard scepticism, especially among older business owners, about the implementation of the digitalisation strategy in sales and distribution. Many retailers attribute this scepticism to a lack of resources, especially now after the long lockdown. Here, retailers should rely on trusted networks and also new 
stakeholders and partners. Retailers are not alone in this situation and the environment (retail eco-system) appreciates the added value that retailers bring to the cities - our city centres, in small, medium and large cities - get a liveable atmosphere through the "small shops". It can also be "friends \& family" who support the transformation - perhaps the children or grandchildren, the generation of "digital natives". For example, an older owner who has been running her business for over 50 years told me that her granddaughter, who is active on Instagram, helped her to digitally set up her traditional business to get over the lockdown. She was surprised and thrilled with the positive outcome. Already after the first day on "Insta", she was greeted in the morning the following day by a long line of young people in front of her shop, all wanting to buy her hats. Digitisation has not only saved your business through the lockdown period, but has also given you access to a new customer base.

But other groups (stakeholders) - institutes, associations, educational institutions e.g. chambers of industry and commerce (IHK) and universities of applied sciences (HAW) can also accompany this transformation. They have the expert knowledge and young, creative minds. It is in the interest of the citizens to preserve the retailers, because they are an enrichment for all of us and bring diversity and liveliness to our cities. It would be a great loss and very sad if these small, cosy shops were lost in the course of the lockdown.

\section{Summary and outlook}

The economic consequences of the lockdown affect small stationary retailers particularly hard. However, at around $80 \%$, micro-enterprises with fewer than ten employees make up the largest share of the industry. It is precisely these small retailers that shape the picture in Germany's city centres. Due to the lockdown in spring 2020 and the still ongoing second lockdown since December, which led to sales slumps of around $80 \%$, many are facing financial ruin. More than half of the stationary shops estimate that they will not survive the year 2021 without help.

The federal government has taken many measures to support retailers in this severe crisis; comprehensive direct financial aid payments, guarantees, tax aid as well as adjustments to the short-time work regulations have been initiated, but many retailers still complain that these measures are too bureaucratic and that the aid does not arrive at all or only late. The voices of retailers and their lobbyists are also getting louder and louder that a realistic strategy for an end to the lockdown and an opening of the shops is missing on the part of politics.

Looking for solutions from the state alone does not seem to be a good way forward. The entrepreneurial spirit of the retailer is needed. Some practical examples have shown how retailers have successfully dealt with the crisis through creativity and agility: the introduction/expansion of online shops, online shopping, social media channels (especially Instagram and
WhatsApp), online calls, click and collect were quickly introduced successfully. The survival strategy in the crisis is digitalisation and customer loyalty.

The "shopping experience" has to be rethought and repositioned. Retailers, who often have limited resources, do not have to tackle this transition alone. Experts can be called in as advisors, such as chambers of industry and commerce (IHK) or universities of applied sciences (HAW) to support these processes and conversions. As Christine Lagarde said in an online interview with the Economist magazine a few weeks ago - it would be very sad if the small retailers disappeared from our cities because they couldn't withstand financially, because they bring diversity and joy and make cities liveable. I think she speaks for all of us. [25]

\section{References:}

1. Handelsverband Deutschland, KMU-Definitionen, Retrieved from: https://einzelhandel.de/index.php?option=com_cont ent\&view=article \&id=974

2. Statistisches Bundesamt, Kleine und mittlere Unternehmen (KMU), Retrieved from: https://www.destatis.de/DE/Themen/BranchenUnternehmen/Unternehmen/Kleine-UnternehmenMittlere-Unternehmen/Glossar/kmu.html

3. Statistisches Bundesamt, Verteilung der Unternehmen in Deutschland nach Unternehmensgröße im Jahr 2018, Retrieved from: https://de.statista.com/statistik/daten/studie/731901/ umfrage/verteilung-unternehmen-in-deutschlandnach-unternehmensgroesse/

4. Handelsverband Deutschland, Auswirkungen der Coronavirus-Krise auf den Einzelhandel: Viele Handelsunternehmen leiden unter sinkender Kundennachfrage, Retrieved from: https://einzelhandel.de/presse/aktuellemeldungen/1 2594-auswirkungen-der-coronavirus-krise-auf-deneinzelhandel-viele-handelsunternehmen-leidenunter-sinkender-kundennachfrage

5. Handelsverband Deutschland, Pressekonferenz des Einzelhandels, Retrieved from: https://einzelhandel.de/hdepk

6. Statistisches Bundesamt, Anzahl der KMU in Deutschland nach Wirtschaftszweigen im Jahr 2018, Retrieved from: https://de.statista.com/statistik/daten/studie/731975/ umfrage/anzahl-der-kmu-in-deutschland-nachwirtschaftszweigen/

7. U. Bentele, Zukunft Einzelhandel - Was kommt, wenn Corona geht? Retrieved from: https://www.rbb-online.de/doku/x-z/zukunfteinzelhandel-was-kommt-wenn-corona-geht.html

8. SWR, Wirtschaft im Corona-Schock - wie überstehen wir die Krise? Retrieved from: https://www.ardmediathek.de/swr/video/betrifft/wir tschaft-im-corona-schock-wie-ueberstehen-wir-diekrise/swrfernsehen/Y3JpZDovL3N3ci5kZS9hZXgvbzEyND c3NDk/ 
9. Bundesagentur für Arbeit, Kurzarbeitergeld, Retrieved from: https://www.arbeitsagentur.de/m/corona-kurzarbeit/

10. Bundesministerium für Arbeit und Soziales, Erleichtertes Kurzarbeitergeld, Retrieved from: https://www.bmas.de/DE/Corona/erleichterteskurzarbeitergeld.html

11. Bundesagentur für Arbeit, Angezeigte Kurzarbeit Deutschland, West/Ost, Länder, Kreise und Agenturen für Arbeit (Zeitreihe Monatszahlen), Retrieved from: https://statistik.arbeitsagentur.de/SiteGlobals/Forms /Suche/Einzelheftsuche_Formular.html?nn=20726 \&topic f=kurzarbeit

12. Handelsblatt, Kurzarbeit sinkt leicht - Starker Anstieg im Handel, Retrieved from: https://www.handelsblatt.com/politik/deutschland/i fo-institut-kurzarbeit-sinkt-leicht-starker-anstiegim-handel/26766054.html?ticket=ST-2839684jTrsCuJUFnMTM5LjbmVb-ap2

13. ifo Institut, Tabelle: Kurzarbeit nach Branchen, Retrieved from: https://www.ifo.de/themen/coronavirus

14. Bundesministerium der Finanzen, Kampf gegen Corona: Größtes Hilfspaket in der Geschichte Deutschlands, Retrieved from: https://www.bundesfinanzministerium.de/Content/ DE/Standardartikel/Themen/Schlaglichter/CoronaSchutzschild/2020-03-13-Milliarden-Schutzschildfuer-Deutschland.html

15. Bundesministerium für Wirtschaft und Energie, Bundesministerium der Finanzen, FAQ zur „Corona-Überbrückungshilfe I für kleine und mittelständische Unternehmen", Retrieved from: https://www.ueberbrueckungshilfeunternehmen.de/UBH/Redaktion/DE/FAQ/FAQs/fa q-liste-01.html?nn=2323344

16. M. Greive, J. Hildebrand, D. Neuerer, and F. Specht, Chaos bei den Corona-Hilfen: Das müssen Unternehmen jetzt wissen, Retrieved from: https://www.handelsblatt.com/politik/deutschland/u eberbrueckungshilfe-chaos-bei-den-corona-hilfendas-muessen-unternehmen-jetztwissen/26793762.html?ticket=ST-2651550u7uG79D4unfmMBC0X5Ad-ap2

17. Bundesministerium der Finanzen, Überbrückungshilfe vereinfacht und verbessert, Retrieved from: https://www.bundesfinanzministerium.de/Content/ DE/Standardartikel/Themen/Schlaglichter/CoronaSchutzschild/2021-01-19-ueberbrueckungshilfeverbessert.html

18. Bundesministerium für Wirtschaft und Energie, Eckpunkte „Corona-Soforthilfe für Kleinstunternehmen und Soloselbständige“,Retrieved from: https://www.bmwi.de/Redaktion/DE/Downloads/E/ eckpunkte-corona-soforthilfe.html

19. K. Köster, Corona-Hilfen werden kaum abgerufen, Retrieved from: https://www.stuttgarternachrichten.de/inhalt.coronavirus-corona-hilfen- werden-kaum-abgerufen.2e037953-2541-42e98284-89ab853f06fd.html

20. T. Hoppe, Firmen erhalten mehr Spielraum bei Hilfen, Retrieved from: https://www.handelsblatt.com/politik/deutschland/c oronakrise-firmen-erhalten-mehr-spielraum-beihilfen/26888620.html?nlayer=Themen 11804704

21. M. Greive, J. Hildebrand, and K. Stratmann, Späte Auszahlung: Wer ist schuld am CoronahilfenDebakel? Retrieved from: https://www.handelsblatt.com/politik/deutschland/u nternehmensgelder-spaete-auszahlung-wer-istschuld-am-coronahilfendebakel/26914424.html?nlayer=Themen_11804704

22. Handelsverband Deutschland, Corona-Gipfel: Politik versagt - keine Perspektive für den Handel, (2021, Feburary 11), Retrieved from: https://einzelhandel.de/presse/aktuellemeldungen/1 3181-corona-gipfel-politik-versagt-keineperspektive-fuer-den-hande

23. RKI, ControlCOVID Strategie und Handreichung zur Entwicklung von Stufenkonzepten bis Frühjahr 2021, (2021, February 18), Retrieved from: https://www.rki.de/SiteGlobals/Forms/Suche/servic eSucheForm.html;jsessionid=B38FFA56AAA2669 9C2DA9FF7E1F7AA8B.internet061? $\mathrm{nn}=2725444$ \&input $=2386720 \&$ gts $=2725442 \_$list $\% 253$ DdateO fIssue_dt\%252Bdesc\&resourceId=2390936\&submi t.x $=0 \&$ submit. $y=0 \&$ searchEngineQueryStrin

24. YourLocal, Dein Online-Marktplatz, Retrieved from: https://magdeburg.store/start

25. C. Lagarde, Editor's conversations: Christine Lagarde, president of the European Central Bank, (2021, February 11), Retrieved from: https://economistsubsevents.zoom.us/rec/play/s8XPja9t4UzxPYZW d1W8dIIDLBvwkGqJNxl8EcMAIunBJ1pvNh_YTiWmYa1QpCAYgw0Qv7 63rniURBe.6vUJQh64GCEDO-cV 